\title{
Potent $\mathrm{P}_{2} \mathrm{Y}_{6}$ receptor mediated contractions in human cerebral arteries
}

\author{
Malin Malmsjö*1, Mingyan Hou ${ }^{1}$, William Pendergast ${ }^{3}$, David Erlinge ${ }^{2}$ and \\ Lars Edvinsson ${ }^{1}$
}

\begin{abstract}
Address: ${ }^{1}$ Division of Experimental Vascular Research, Department of Internal Medicine, Lund University Hospital, Lund, Sweden, ${ }^{2}$ Department of Cardiology, Lund University Hospital, Lund, Sweden and ${ }^{3}$ Inspire Pharmaceuticals Inc., Durham, North Carolina, USA

Email: Malin Malmsjö* - malin.malmsjo@med.lu.se; Mingyan Hou - mingyan.hou@med.lu.se; William Pendergast - wpenderg@calpoly.edu; David Erlinge - david.erlinge@telia.com; Lars Edvinsson - lars.edvinsson@med.lu.se

* Corresponding author
\end{abstract}

Published: 9 May 2003

BMC Pharmacology 2003, 3:4

This article is available from: http://www.biomedcentral.com/I47I-22/0/3/4

(C) 2003 Malmsjö et al; licensee BioMed Central Ltd. This is an Open Access article: verbatim copying and redistribution of this article are permitted in all media for any purpose, provided this notice is preserved along with the article's original URL.
Received: 22 January 2003

Accepted: 9 May 2003

\begin{abstract}
Background: Extracellular nucleotides play an important role in the regulation of vascular tone and may be involved in cerebral vasospasm after subarachnoidal haemorrhage. This study was designed to characterise the contractile $\mathrm{P} 2$ receptors in endothelium-denuded human cerebral and omental arteries. The isometric tension of isolated vessel segments was recorded in vitro. P2 receptor mRNA expression was examined by RT-PCR.

Results: In human cerebral arteries, the selective $\mathrm{P}_{2} \mathrm{Y}_{6}$ receptor agonist, UDP $\beta S$ was the most potent of all the agonists tested $\left(\mathrm{pEC}_{50}=6.8 \pm 0.7\right)$. The agonist potency; UDP $\beta S>\alpha \beta-M e A T P>$ $\mathrm{UTP} \gamma \mathrm{S}>\mathrm{ATP} \gamma \mathrm{S}>\mathrm{ADP} \beta \mathrm{S}=0$, indicated the presence of contractile $\mathrm{P} 2 \mathrm{X}_{1} \mathrm{P}_{2} \mathrm{Y}_{2}, \mathrm{P}_{2} \mathrm{Y}_{4}$ and $\mathrm{P} 2 \mathrm{Y}_{6}$, but not P2Y, receptors, in human cerebral arteries. In human omental arteries, UDP $\beta S$ was inactive. The agonist potency; $\alpha \beta-M e A T P>A T P \gamma S=U T P \gamma S>A D P \beta S=U D P \beta S=0$, indicated the presence of contractile $\mathrm{P} 2 \mathrm{X}_{1}$, and $\mathrm{P} 2 \mathrm{Y}_{2}$ receptors, but not $\mathrm{P} 2 \mathrm{Y}_{1}$ or $\mathrm{P} 2 \mathrm{Y}_{6}$ receptors, in human omental arteries. RT-PCR analysis of endothelium-denuded human cerebral and omental arteries demonstrated $P 2 X_{1}, P 2 Y_{1}, P 2 Y_{2}$ and $P 2 Y_{6}$ receptor $m R N A$ expression. There were no bands for the $\mathrm{P}_{2} \mathrm{Y}_{4}$ receptor $\mathrm{mRNA}$ in the omental arteries, while barely detectable in the cerebral arteries.

Conclusions: $\mathrm{P}_{2} \mathrm{Y}_{6}$ receptors play a prominent role in mediating contraction of human cerebral arteries. Conversely, no such effect can be observed in human omental arteries and previous results confirm the absence of $\mathrm{P}_{2} \mathrm{Y}_{6}$ receptors in human coronary arteries. The $\mathrm{P}_{2} \mathrm{Y}_{6}$ receptor might be a suitable target for the treatment of cerebral vasospasm.
\end{abstract}

\section{Background}

There is evidence of the release of adenosine triphosphate (ATP) from endothelial cells, platelets, and sympathetic nerves as well as from damaged cells in atherosclerosis, hypertension, restenosis and ischemia [1]. Uridine tri- phosphate (UTP) has been shown to be released from endothelial cells in response to flow and shear stress [2], and it has been isolated from platelets [3]. Since UTP is particularly present in the brain and has potent vasoconstrictor actions in human cerebral arteries, it may play a role in 
cerebral vasospasm after subarachnoidal haemorrhage [4-6].

Extracellular nucleotides induce vasodilatation by activating P2Y receptors on endothelial cells, while vasoconstriction is mediated by $\mathrm{P} 2 \mathrm{Y}$ and $\mathrm{P} 2 \mathrm{X}$ receptors on vascular smooth muscle cells. When the endothelial function is damaged in pathological conditions such as subarachnoidal haemorrhage or arteriosclerosis the vasoconstrictor actions dominate, causing cerebral vasospasm [7].

Recent receptor cloning has proven the existence of several different P2X and P2Y receptor subtypes, and there is evidence that five of these elicit vascular response when stimulated by extracellular nucleotides, namely $\mathrm{P} 2 \mathrm{X}_{1}$, $\mathrm{P}_{2} \mathrm{Y}_{1}, \mathrm{P}_{2} \mathrm{Y}_{2}, \mathrm{P}_{2} \mathrm{Y}_{4}$ and P2Y 6 [8,9]. Expression of these receptors in cells has enabled characterisation of their respective pharmacological profile. $\mathrm{P}_{2} \mathrm{X}_{1}$ receptors have been shown by immunohistochemistry to be the dominant P2X receptor on smooth muscle cells in the vasculature $[10,11] . \quad P 2 X_{1}$ receptors are activated by $\alpha \beta$ methylene-adenosine triphosphate $(\alpha \beta$-MeATP) > ATP with no effect of uridine triphosphate (UDP) or UTP [12]. At the $\mathrm{P}_{2} \mathrm{Y}_{1}$ receptor adenosine 5'-O-3-thiodiphosphate (ADP $\beta S$ ) and adenosine diphosphate (ADP) have greater potency than ATP, while UTP and UDP are inactive $[13,14]$. The $\mathrm{P}_{2} \mathrm{Y}_{2}$ receptor is activated with similar potencies by ATP and UTP but not by ADP or UDP; the human $\mathrm{P}_{2} \mathrm{Y}_{4}$ receptor is activated most potently by UTP, less potently by ATP, and not at all by nucleotide diphosphates; and the $\mathrm{P}_{2} \mathrm{Y}_{6}$ receptor is activated most potently by UDP but weakly by UTP, ADP and ATP [15].

However, the identification of $\mathrm{P} 2$ receptors expressed on smooth muscle cells is difficult particularly because of the absence of truly selective agonists and antagonists. Ligand instability complicates the analyses especially when performed in intact tissues as nucleotide triphosphates are rapidly metabolised by ectonucleotidases on the extracellular surface of cells [16]. In addition, commercial nucleotides are impure. Stable nucleotides have recently started to be used in attempts to pharmacologically define the $\mathrm{P} 2 \mathrm{Y}$ receptor subtypes. These include uridine 5'-O-thiodiphosphate (UDP $\beta S$ ), uridine 5'-O-3-thiotriphosphate (UTP $\gamma$ S), adenosine 5 '-O-thiodiphosphate (ADP $\beta S$ ) and adenosine 5'-O-3-thiotriphosphate (ATP $\gamma \mathrm{S}$ ) that contain a modification of the nucleotide triphosphate group in the form of a thio substitution at the terminal phosphate, which provides stability to ectonucleotidase action. UT$\mathrm{P} \gamma \mathrm{S}$ is a potent and enzymatically stable agonist at the human $\mathrm{P}_{2} \mathrm{Y}_{2}$ and $\mathrm{P}_{2} \mathrm{Y}_{4}$ receptors, while UDP $\beta S$ has recently shown to selectively activate the $\mathrm{P}_{2} \mathrm{Y}_{6}$ receptors $[17,18]$. It is therefore now possible to discriminate between the vascular effects of different pyrimidine activated $\mathrm{P} 2$ receptor subtypes.
In the design of future cerebrovascular therapeutics it is important that the contractile responses of extracellular nucleotides is characterised in human subjects. This study was designed to evaluate the relative contribution of the different P2Y receptor subtypes that mediate the contractile response in human cerebral and omental arteries, which has not been done before by use of the stable pyrimidines UDP $\beta S$ and UTP $\gamma$.

\section{Results \\ Vasomotor responses}

After endothelium removal, the vasodilatory response to acetylcholine in UTP preconstricted arteries was abolished, indicating a properly removed endothelium. Furthermore, vascular smooth muscle cell function was considered intact, since the contractile response to 60 $\mathrm{mmol} / \mathrm{L} \mathrm{K}^{+}$was unaffected. P2X receptors were desensitised by addition of $10 \mu \mathrm{mol} / \mathrm{L} \alpha \beta$-MeATP. This elicited a transient contraction. After 8 min the tension was back to baseline and if $\alpha \beta$-MeATP was added a second time, no contraction could be observed, indicating desensitised P2X receptors.

The contractile capacity of the arteries was examined by addition of $60 \mathrm{mmol} / \mathrm{L} \mathrm{K}^{+}$. For the cerebral arteries the contractile response to $60 \mathrm{mmol} / \mathrm{L} \mathrm{K}^{+}$amounted to $2.7 \pm$ $1.3 \mathrm{mN}$ above baseline tension and, for omental arteries, to $8.2 \pm 0.8 \mathrm{mN}$. The nucleotide-induced contractions were thereafter calculated as percent of this $\mathrm{K}^{+}$-contraction in respective vessel segment.

\section{Human cerebral arteries}

$\alpha \beta$-MeATP induced potent contractions of the human cerebral arteries, indicating effects of contractile P2X receptors. After P2X receptor desensitisation (see methods), further experiments were performed to analyse P2Y receptor mediated vasoconstrictions. The endogenous nucleotides, UDP and UTP, elicited contractions of similar potencies $\left(\mathrm{pEC}_{50}=5.5 \pm 0.2\right.$ and $5.3 \pm 0.2, P=$ n.s. $)$. Further experiments were therefore performed using the stable nucleotide analogues UDP $\beta S, U T P \gamma S$, ATP $\gamma S$ and ADP $\beta$ S. Notably, the selective $\mathrm{P}_{2} \mathrm{Y}_{6}$ receptor agonist, UDP $\beta S$, was one log unit more potent than UDP in the human cerebral arteries $\left(\mathrm{pEC}_{50}=6.8 \pm 0.2\right.$ and $5.5 \pm 0.2$, $P<0.001$ ), making it the most potent of all agonists tested. ATP and ADP induced contractions only at $\mathrm{mmol} / \mathrm{L}$ concentrations. The stable purine, ATP $\gamma \mathrm{S}$, induced a considerably more potent contraction than ATP $\left(\mathrm{pEC}_{50}=3.0\right.$ \pm 0.2 for ATP and $4.8 \pm 0.2$ for ATP $\gamma, P<0.001)$. The AT$\mathrm{P} \gamma \mathrm{S}$ concentration-response curve resembled that of UT$\mathrm{P} \gamma \mathrm{S}$, indicating involvement of $\mathrm{P}_{2} \mathrm{Y}_{2}$ receptors. On the other hand, ADP $\beta S$ had no effect, indicating that there are no contractile $\mathrm{P}_{2} \mathrm{Y}_{1}$ receptors. 
In conclusion, the potency order for the agonists in human cerebral arteries was: UDP $\beta S>\alpha \beta$-MeATP $>$ UTP $\gamma$ S > $\mathrm{ATP} \gamma \mathrm{S}>\mathrm{ADP} \beta \mathrm{S}=0$, indicating involvement of contractile $\mathrm{P}_{2} \mathrm{X}_{1}, \mathrm{P}_{2} \mathrm{Y}_{2}, \mathrm{P}_{2} \mathrm{Y}_{4}$ and $\mathrm{P}_{2} \mathrm{Y}_{6}$, but not $\mathrm{P}_{2} \mathrm{Y}_{1}$ receptors, in human cerebral arteries. All data are presented in Table 1. For data concerning the endogenous nucleotides in the cerebral circulation, see Fig 1a. the stable nucleotides, see Fig 2a.

\section{Human omental arteries}

$\alpha \beta$-MeATP induced potent contractions of the human omental arteries, indicating effects of contractile P2X receptors. After P2X receptor desensitisation (see methods), further experiments were performed to analyse P2Y receptor mediated vasoconstrictions. The endogenous nucleotides, UTP and UDP, only induced contraction at a high concentration $(\mathrm{mM})$. Conversely, the stable pyrimidines, UDP $\beta S$ and UTP $\gamma$ S, had a markedly different pharmacological profile. Unlike the cerebral arteries, UDP $\beta S$ was inactive in the human omental arteries, indicating that there are no contractile $\mathrm{P}_{2} \mathrm{Y}_{6}$ receptors. The potency of UTP $\gamma \mathrm{S}$ was one log unit higher than that for UTP $\left(\mathrm{pEC}_{50}=4.3 \pm\right.$ 0.1 and $3.3 \pm 0.1, P<0.001$ ), indicating stability to ectonucleotidase activity. UTP $\gamma \mathrm{S}$ and ATP $\gamma \mathrm{S}$ induced vasoconstriction might be a result of $\mathrm{P}_{2} \mathrm{Y}_{2}$ or $\mathrm{P}_{2} \mathrm{Y}_{4}$ receptor activation in omental arteries. Like in the cerebral arteries, ADP $\beta S$ did not induce vasoconstriction in the omental arteries, indicating that contractile $\mathrm{P}_{2} \mathrm{Y}_{1}$ receptors do not play a role.

In conclusion, the potency order for the agonists in the human omental arteries was; $\alpha \beta$-MeATP $>$ ATP $\gamma S=U T P \gamma S$ $>\mathrm{ADP} \beta S=\mathrm{UDP} \beta \mathrm{S}=0$, indicating the presence of contractile $\mathrm{P} 2 \mathrm{X}_{1}$ and $\mathrm{P} 2 \mathrm{Y}_{2}$ receptors, but not $\mathrm{P}_{2} \mathrm{Y}_{1}$ or $\mathrm{P} 2 \mathrm{Y}_{6}$ receptors, in human omental arteries. All data are presented in Table 1 . For data concerning the endogenous nucleotides in the cerebral circulation, see Fig $1 \mathrm{~b}$. the stable nucleotides, see Fig $2 b$.

\section{RT-PCR}

Agarose gel electrophoresis of PCR products from endothelium-denuded, human cerebral and omental arteries demonstrated products of the expected size for the corresponding mRNA encoding human $\mathrm{P}_{2} \mathrm{X}_{1}$ (383 base pairs), $\mathrm{P}_{2} \mathrm{Y}_{1}$ (550 base pairs), $\mathrm{P}_{2} \mathrm{Y}_{2}$ (432 base pairs) and ${\mathrm{P} 2 \mathrm{Y}_{6}}_{6}$ receptors (526 base pairs) (Fig. 3). There were no bands for the $\mathrm{P}_{2} \mathrm{Y}_{4}$ receptor mRNA ( 530 base pairs) in the omental arteries, while these were barely detected in the cerebral arteries. No bands were detected in controls without an RT-step.

\section{Discussion}

The stable pyrimidines, UTP $\gamma$ S and UDP $\beta$ S, were here for the first time used to characterise the P2 receptor subtypes that mediate vasoconstriction in human cerebral and omental arteries. The novel findings include that the $\mathrm{P}_{2} \mathrm{Y}_{6}$ receptors play a prominent role in mediating contraction of cerebral arteries. Conversely, no such effect can be observed in omental arteries and previous results confirm the absence of $\mathrm{P}_{2} \mathrm{Y}_{6}$ receptors in human coronary arteries [26]. The marked effects of the $\mathrm{P}_{2} \mathrm{Y}_{6}$ receptor in the cerebral circulation might make it a suitable target for treatment of diseases with cerebral vasospasm.

Study of P2Y receptors has been a challenge due to the paucity of pharmacological tools for identification of receptor subtypes. Since truly selective antagonists have not yet been developed, the characterisation of P2Y receptors has mainly been performed by monitoring agonist responses. This causes difficulties, as the endogenous nucleotides UTP, UDP, ATP and ADP are neither selective nor stable. However, recent studies present the stable pyrimidines UTP $\gamma$ S, UDP $\beta S$ as unique pharmacological tools that facilitate the characterisation of $\mathrm{P} 2 \mathrm{Y}$ receptor subtypes in intact tissues $[26,27]$. The present results clearly demonstrate the importance of stable nucleotides in the characterisation of receptors in tissue preparations with ectonucleotidase activity: In the cerebral arteries, UTP and UDP were equipotent while the stable pyrimidines demonstrated a 1.5 log unit higher potency for UDP $\beta S$ as compared to UTP $\gamma$ S. UDP gave contractions in the omental arteries with low potency, but this could not be reproduced by UDP $\beta S$, indicating that UDP was enzymatically converted to UTP. Likewise, ADP induced contractions in both cerebral and omental arteries, which could not be reproduced by ADP $\beta$ S. Thus, the endogenous nucleotides may both underestimate and overestimate the contribution of different P2Y receptor subtypes, and previous studies using non-stable nucleotides should be interpreted with caution.

Extracellular nucleotides are released from blood clots during subarachnoidal haemorrhage $[28,29]$. Since both UDP and UTP are particularly present in the brain and produce sustained contraction of cerebral blood vessels, these have been postulated to contribute in the genesis of vasospasm after subarachnoidal haemorrhage $[4,6]$. The present results that UTP and UDP were equipotent in inducing contraction of cerebral arteries has also been shown by others $[4,30]$. Therefore, stable nucleotides were used to further characterise the pyrimidines sensitive $\mathrm{P} 2 \mathrm{Y}$ receptors that mediated this vasoconstrictor response.

In the human cerebral arteries, UDP $\beta S$ was $1.5 \log$ units more potent than UTP $\gamma$ S, indicating prominent effects by the $\mathrm{P}_{2} \mathrm{Y}_{6}$ receptor. Interestingly, UDP $\beta S$ did not act as a vasoconstrictor in human omental arteries, which is in accordance with a previous study of human coronary arteries where UDP $\beta S$ also lacked an effect [26]. It is well known that receptor distribution varies between different 


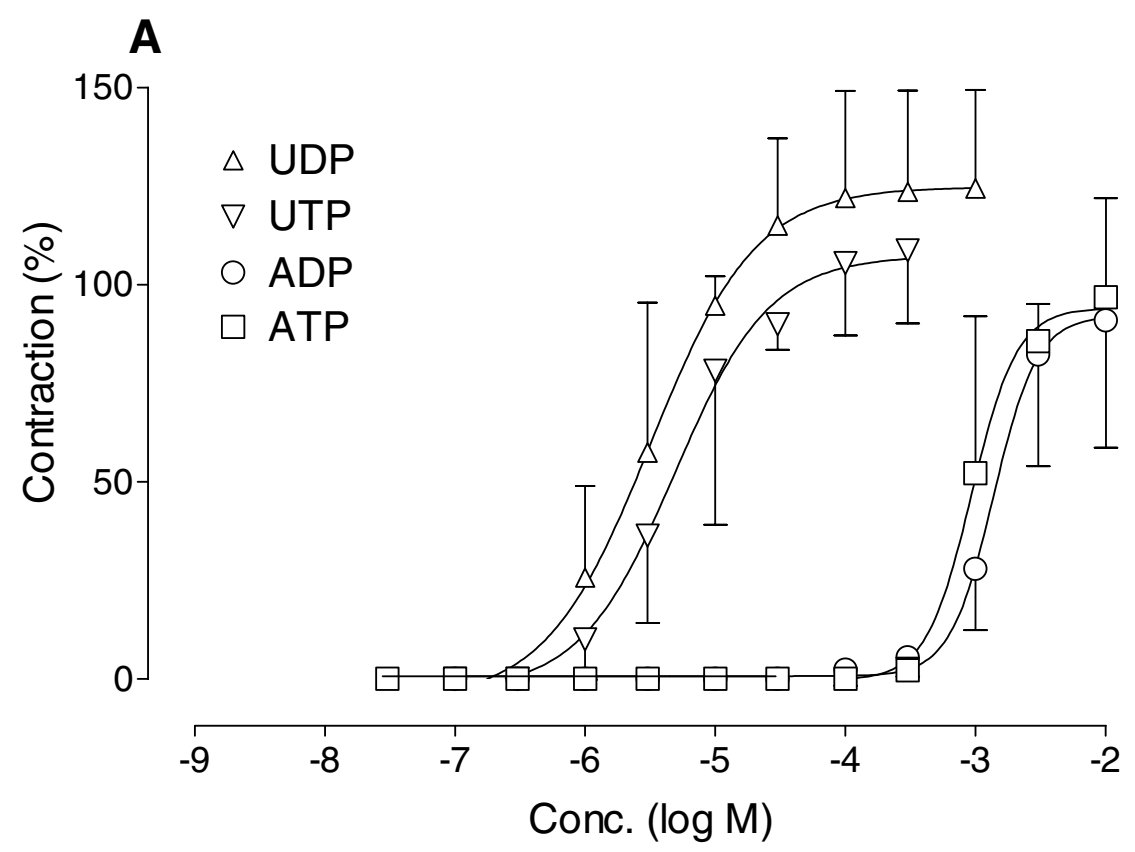

B

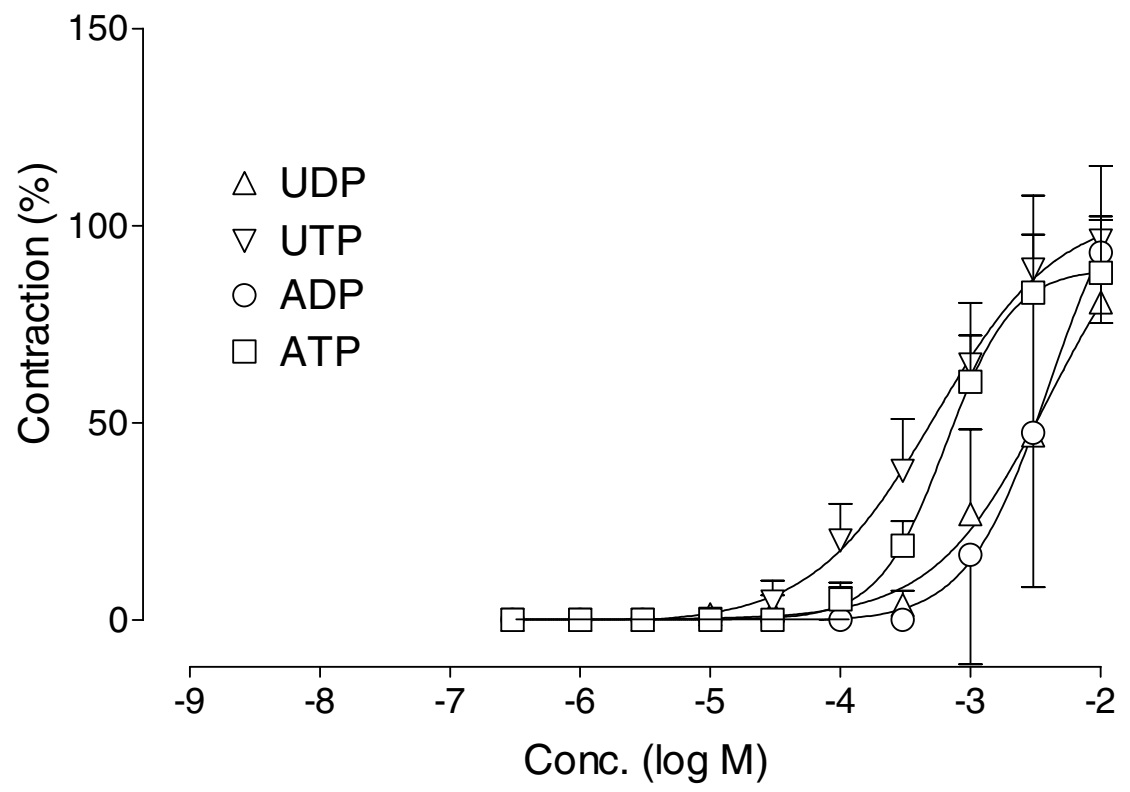

Figure I

Concentration-dependent contractions to UDP, UTP, ADP and ATP in (A) human cerebral arteries and (B) human omental arteries. UDP, UTP, ADP and ATP were added after P2X receptor desensitisation with $10 \mu \mathrm{mol} / \mathrm{L} \alpha \beta-M e A T P$. Contractions are expressed as percentage of the response to $60 \mathrm{mmol} / \mathrm{L} \mathrm{K}^{+}$. Data are shown as mean values \pm S.E.M of 6 experiments (patients). 


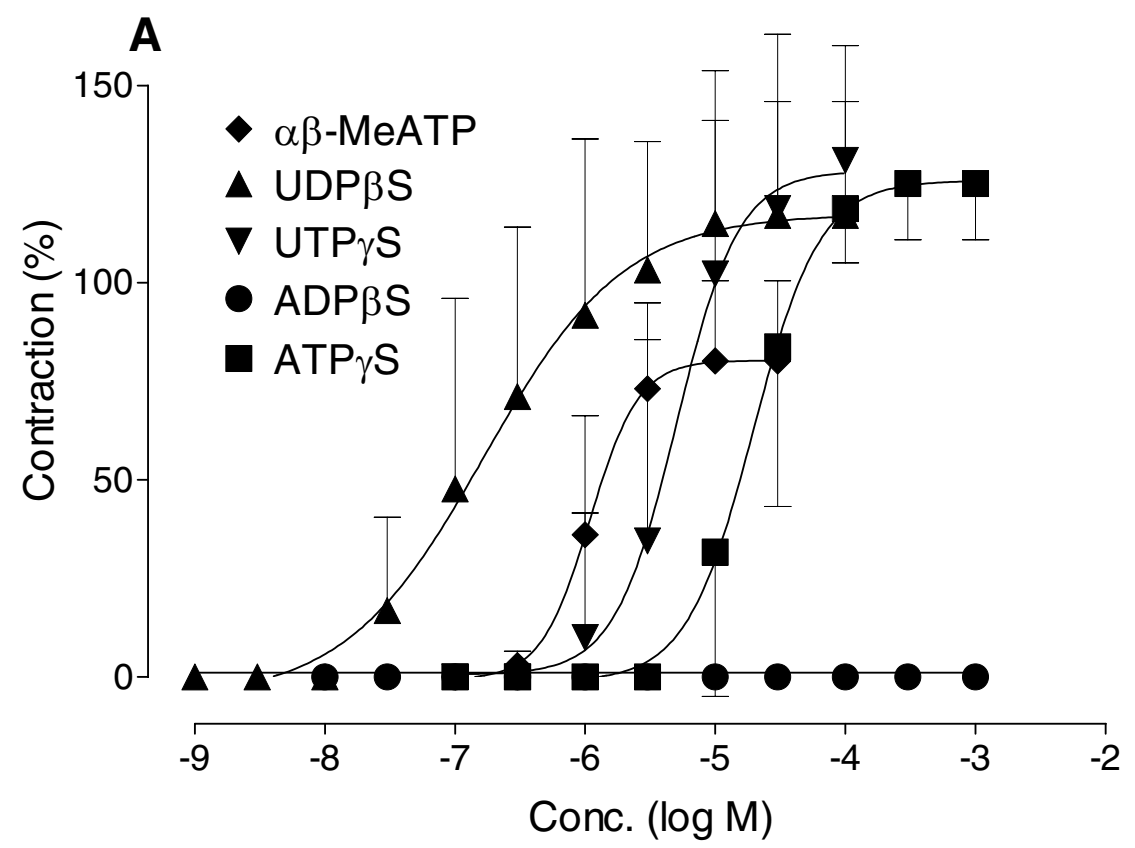

B

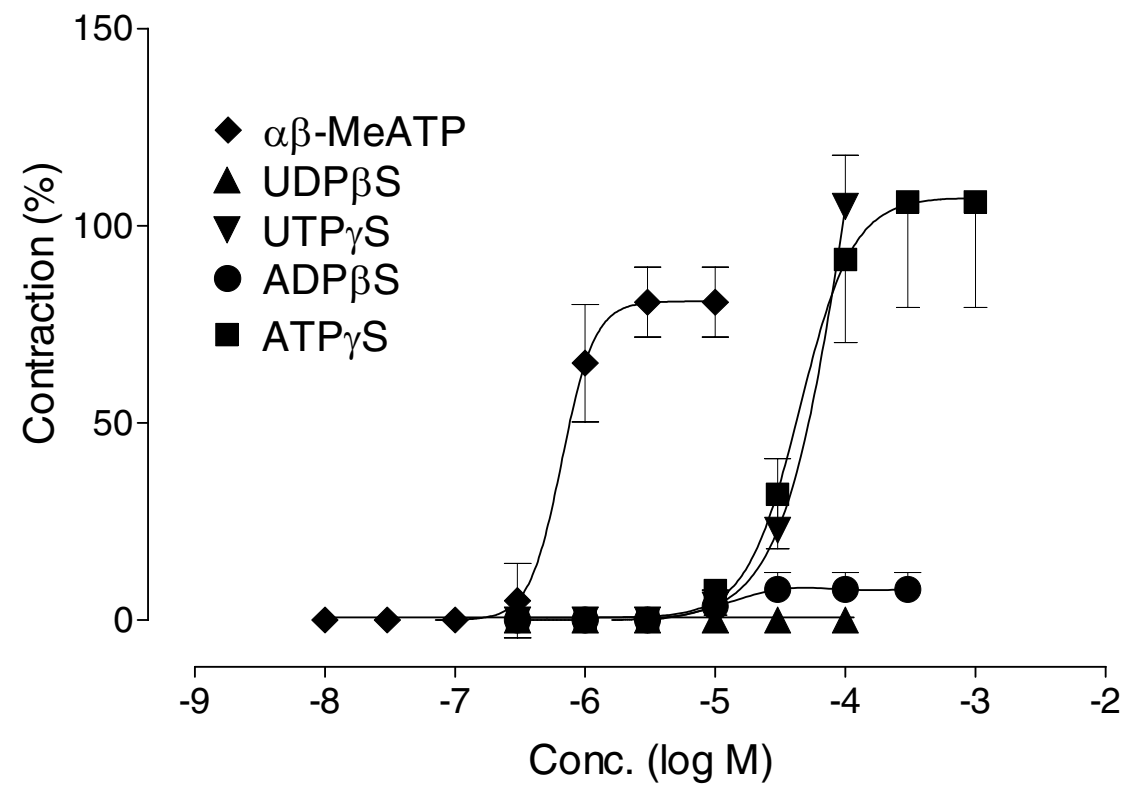

Figure 2

Concentration-dependent contractions to $\alpha \beta$-MeATP, UDP $\beta S$, UTP $\gamma$ S, ADP $\beta$ S and ATP $\gamma$ S in (A) human cerebral arteries and (B) human omental arteries. UDP $\beta$ S UTP $\gamma$ S, ADP $\beta S$ and ATP $\gamma$ S were added after P2X receptor desensitisation with I0 $\mu$ mol/ $\mathrm{L} \alpha \beta-M e A T P$. Contractions are expressed as percentage of the response to $60 \mathrm{mmol} / \mathrm{L} \mathrm{K}^{+}$. Data are shown as mean values \pm S.E.M of 6 experiments (patients). 
Table I: Contractile responses to extracellular nucleotides in human cerebral and omental arteries.

\begin{tabular}{|c|c|c|c|c|}
\hline & Cerebral arteries & & Omental arteries & \\
\hline & $\mathrm{pEC}_{50}(-\log \mathrm{mol} / \mathrm{L})$ & $\mathrm{E}_{\max }(\%)$ & $\mathrm{pEC}_{50}(-\log \mathrm{mol} / \mathrm{L})$ & $\mathrm{E}_{\max }(\%)$ \\
\hline$\alpha \beta-M e A T P$ & $6.0 \pm 0.1$ & $80 \pm 8$ & $6.2 \pm 0.1$ & $81 \pm 2$ \\
\hline UDP & $5.5 \pm 0.2$ & $128 \pm 16$ & $2.7 \pm 0.2$ & $81 \pm 9$ \\
\hline UDPßS & $6.8 \pm 0.2$ & $117 \pm 8$ & - & $0 \pm 0$ \\
\hline UTP & $5.3 \pm 0.2$ & $110 \pm 10$ & $3.3 \pm 0.1$ & $96 \pm 8$ \\
\hline UTP $\gamma \mathrm{S}$ & $5.3 \pm 0.1$ & $13 \mid \pm 10$ & $4.3 \pm 0.1$ & $105 \pm 7$ \\
\hline$A D P$ & $2.9 \pm 0.1$ & $91 \pm 23$ & $2.6 \pm 0.2$ & $96 \pm 7$ \\
\hline$A D P \beta S$ & $0.0 \pm 0.0$ & - & - & $8 \pm 4$ \\
\hline ATP & $3.0 \pm 0.2$ & $97 \pm 25$ & $3.2 \pm 0.1$ & $88 \pm 6$ \\
\hline ATP $\gamma \mathrm{S}$ & $4.8 \pm 0.2$ & $125 \pm 8$ & $4.4 \pm 0.1$ & $106 \pm 11$ \\
\hline
\end{tabular}

All nucleotides, except $\alpha \beta$-MeATP, were added after desensitisation of $\mathrm{P} 2 \mathrm{X}$ receptors with $10 \mu \mathrm{mol} / \mathrm{L} \alpha \beta-$ MeATP. Contractions are expressed as percentage of an initial contraction induced by $60 \mathrm{mmol} / \mathrm{L} \mathrm{K} \mathrm{K}^{+}$. Data are shown as $\mathrm{E}_{\max } \pm$ S.E.M. and $\mathrm{pEC} \mathrm{C}_{50} \pm \mathrm{S}$.E.M of 6 experiments (patients).

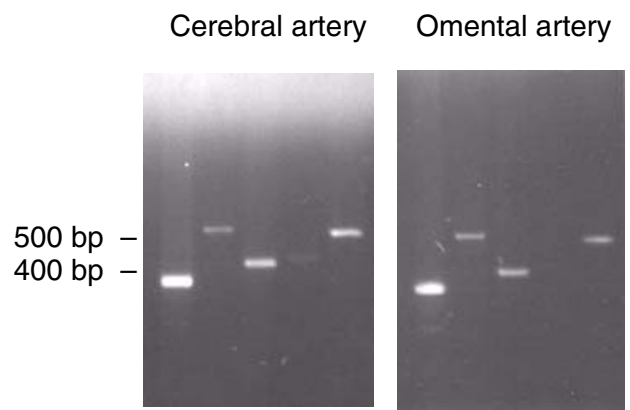

\section{Figure 3}

Electrophoresis of RT-PCR products corresponding to mRNA encoding human $\mathrm{P} 2 \mathrm{X}_{1}, \mathrm{P}_{2} \mathrm{Y}_{1}, \mathrm{P}_{2} \mathrm{Y}_{2}, \mathrm{P}_{2} \mathrm{Y}_{4}$ and $\mathrm{P} 2 \mathrm{Y}_{6}$ receptors (shown from left to right) in human cerebral and omental arteries. The amplified products were of the pre-

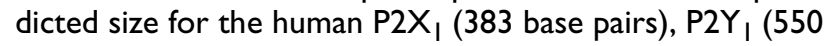
base pairs), $\mathrm{P}_{2} \mathrm{Y}_{2}$ (432 base pairs), $\mathrm{P}_{2} \mathrm{Y}_{4}$ (530 base pairs) and $\mathrm{P}_{2} \mathrm{Y}_{6}$ receptors (526 base pairs). Samples were analysed on a $2 \%$ agarose / ethidium bromide gel at $5 \mathrm{~V} / \mathrm{cm}$, and photographed.

vascular beds in order to obtain a specific blood flow regulation. UTP has been shown to produce prominent contractions in the cerebral circulation, as compared to in the periphery [29]. Furthermore, cerebral arteries were more sensitive to ATP than systemic arteries from the dog heart and mesentery [31].
The similarity in potency between ATP $\gamma$ S (after P2X receptor desensitisation) and UTP $\gamma S$ suggest the presence of contractile $\mathrm{P}_{2} \mathrm{Y}_{2}$ receptors in both cerebral and omental arteries. An effect by the $\mathrm{P}_{2} \mathrm{Y}_{4}$ receptor cannot be excluded since it is also activated by UTP $\gamma$ S. However, RT-PCR analysis could not detect $\mathrm{P}_{2} \mathrm{Y}_{4}$ mRNA expression in the omental arteries. These results indicate that the $\mathrm{P}_{2} \mathrm{Y}_{4}$ receptor is of none or minor importance in mediating vasoconstriction. Similar results have been reported from rat pial arteries where mRNA transcripts for the $\mathrm{P}_{2} \mathrm{Y}_{2}$, but not the $\mathrm{P}_{2} \mathrm{Y}_{4}$ receptor could be amplified [32].

The $\mathrm{P}_{2} \mathrm{Y}_{2}$ effect was less prominent than that for the $\mathrm{P} 2 \mathrm{Y}_{6}$ receptors in human cerebral arteries. UTP has previously been proposed to elicit sustained vasoconstriction and vasospasm after subarachnoidal haemorrhage in cerebral arteries $[4,6]$. In the present experiments, part of the UTP may have been degraded to UDP by ectonucleotidases on the extracellular surface of cells before eliciting vasoconstriction. It is therefore probable that the UTP effects seen in previous reports were really mediated by UDP sensitive $\mathrm{P} \mathrm{Y}_{6}$ receptors, with a lesser contribution of UTP sensitive $\mathrm{P}_{2} \mathrm{Y}_{2}$ receptors.

$\alpha \beta$-MeATP induced a transient contraction both in the human cerebral and omental arteries indicating the presence of $\mathrm{P} 2 \mathrm{X}$ receptors. Since the $\mathrm{P} 2 \mathrm{X}_{1}$ receptor is rapidly desensitised and has been shown to be the dominant subtype in cerebral vascular smooth muscle cells, these are likely to be $\mathrm{P} 2 \mathrm{X}_{1}$ receptors $[32,33]$. In the omental arteries, $\alpha \beta$ MeATP induced a transient contraction that was $2 \log$ units more potent than that of UTP $\gamma$ S and ATP $\gamma$ S. In the cerebral circulation, the case was different. The $\alpha \beta$-MeATP induced contraction was $1 \log$ unit less potent than that of UDP $\beta S$ as well as $30 \%$ less efficacious than the vasoconstriction mediated by $\mathrm{P}_{2} \mathrm{Y}_{6}$ and $\mathrm{P}_{2} \mathrm{Y}_{2}$ receptors. Thus, con- 
Table 2: Specific primers for the human $\mathrm{P} 2 \mathrm{X}_{1}, \mathrm{P}_{2} \mathrm{Y}_{1}, \mathrm{P}_{2} \mathrm{Y}_{2}, \mathrm{P}_{2} \mathrm{Y}_{4}$ and $\mathrm{P} 2 \mathrm{Y}_{6}$ receptors were constructed based on published nucleotide sequences [2I-25], as follows.

\begin{tabular}{|c|c|c|}
\hline Primer & Nucleotide sequence & Product length $\times$ (base pairs) \\
\hline $\mathrm{P} 2 \mathrm{X}_{\mathrm{I}}$ forward & 5'-GTTTGGGATTCGCTTTGA-3' & \\
\hline $\mathrm{P} 2 \mathrm{X}_{\mathrm{I}}$ reverse & 5'-GGCTGAGAGGGTAGGAGAC-3' & 383 \\
\hline$P 2 Y_{\text {, forward }}$ & 5'-ACGGGCTTCCAGTTTTAC-3' & \\
\hline $\mathrm{P} 2 \mathrm{Y}_{\text {, reverse }}$ & 5'-CCAAGGGGACACAGAACA-3' & 550 \\
\hline $\mathrm{P} 2 \mathrm{Y}_{2}$ forward & 5'-СTCTGCTTCCTGCCATTC-3' & \\
\hline $\mathrm{P}_{2} \mathrm{Y}_{2}$ reverse & 5'-GCACAAGTCCTGGTCCTCT-3' & 432 \\
\hline $\mathrm{P}_{2} \mathrm{Y}_{4}$ forward & 5'-CAGCACCAAAGGGACCAC-3' & \\
\hline $\mathrm{P}_{2} \mathrm{Y}_{4}$ reverse & 5'-GCTTGCCACCACCACAGA-3' & 530 \\
\hline $\mathrm{P} 2 \mathrm{Y}_{6}$ forward & 5'-ACAGGCATCCAGCGTAAC-3' & \\
\hline $\mathrm{P} \mathrm{Y}_{6}$ reverse & 5'-CGGACACAATGGCAAATA-3' & 526 \\
\hline
\end{tabular}

tractile $\mathrm{P} 2 \mathrm{Y}$ receptors play a dominating role in the cerebral circulation, as compared to the $\mathrm{P} 2 \mathrm{X}$ receptor effects.

The $\mathrm{P} 2 \mathrm{Y}_{1}$ receptor agonist, ADP $\beta S$, had no contractile effect neither in the cerebral nor in the omental arteries. Studies in animals demonstrate that $\mathrm{P} 2 \mathrm{Y}_{1}$ receptors only mediate endothelium-dependent dilatation in cerebral arteries [32]. Furthermore, 2-MeSADP was recently shown to induce potent dilatations in preconstricted human left internal mammary artery branches, indicating an important role for endothelial $\mathrm{P} 2 \mathrm{Y}_{1}$ receptors [34]. This dilatory response was abolished after the endothelium was removed, providing evidence that there were no dilatory $\mathrm{P}_{2} \mathrm{Y}_{1}$ receptors in these human vascular smooth muscle cells [34]. Likewise, when the endothelium was removed from the rat mesenteric arteries, the ADP $\beta S$ induced dilatation was abolished [27]. PCR analysis demonstrated presence of $\mathrm{P}_{2} \mathrm{Y}_{1}$ receptor mRNA. Although, the endothelium was functionally removed this does not necessarily mean that there are no endothelial cells and mRNA from the same, which might explain the absence of effect by ADP $\beta S$ and presence of $P 2 \mathrm{Y}_{1}$ receptor mRNA. Also, presence of receptor mRNA does not necessarily mean there is functional receptor-protein on the cell surface.

Our results show that the selective $\mathrm{P}_{2} \mathrm{Y}_{6}$ receptor agonist UDP $\beta S$ induce an efficacious and potent constriction of human cerebral arteries, while no such effect can be observed in human omental or coronary arteries [26]. Conversely, mRNA for $\mathrm{P}_{2} \mathrm{Y}_{6}$ receptors was detected in both cerebral and omental arteries. Apparently the $\mathrm{P}_{2} \mathrm{Y}_{6}$ mRNA does not encode functional receptors in the omental arteries. Similar results were previously obtained in coronary arteries [26]. Both UTP and UDP have previously proven to induce dilatation of cerebral arteries [35], although when vasodilatation has been studied by use of the stable pyrimidines, UTP $\gamma \mathrm{S}$ and UDP $\beta S$, no dilatory ef- fect of the $\mathrm{P}_{2} \mathrm{Y}_{6}$ receptor have be observed [26]. Taken together, it is plausible that only vasoconstriction is mediated by $\mathrm{P}_{2} \mathrm{Y}_{6}$ receptors and that this effect is especially prominent in the cerebral circulation.

An interesting observation is the difference in potency in these experiments between the endogenous (UDP and UTP) and the stable nucleotides (UDP $\beta$ S and UTP $\gamma S$ ) and the importance of ectonucleotidases for pyrimidine degradation, as suggested by Lazarowski et al. 1997 [36]. In cell systems, where the influence of ectonucleotidases has been minimised, UTP and UTP $\gamma$ S are equally potent [18], confirming that the increased efficacy and potency by the stable pyrimidines in the present experiments is not due to a structural change that alters the effect at the receptor.

\section{Conclusions}

The stable pyrimidines UTP $\gamma$ S and UDP $\beta$ S are useful tools in the pharmacological P2 receptor characterisation in intact tissues with ectonucleotidase activity. Extracellular nucleotides stimulated contractions of human cerebral arteries primarily by activation of $\mathrm{P}_{2} \mathrm{Y}_{2}, \mathrm{P}_{2} \mathrm{Y}_{6}$ and $\mathrm{P} 2 \mathrm{X}_{1}$ receptors, while a role for $\mathrm{P}_{2} \mathrm{Y}_{1}$ can be excluded. A similar pattern was seen in the omental arteries, except that no $\mathrm{P}_{2} \mathrm{Y}_{6}$ receptor mediated contractions was seen. These results indicate that antagonists of the $\mathrm{P}_{2} \mathrm{Y}_{6}$ receptor, but also the $\mathrm{P} 2 \mathrm{Y}_{2}$ and $\mathrm{P} 2 \mathrm{X}_{1}$ receptors may be useful in the treatment of vasospasm.

\section{Methods \\ Patients}

Cerebral and omental arteries were explanted during tumour surgery from 12 patients that were between 17 and 64 years of age. The cerebral arteries looked macroscopically healthy and were removed from the temporal-parietal cortex. 


\section{Vasomotor studies}

Tissue preparation

The cerebral and omental arteries were immediately immersed in cold oxygenated buffer solution (for composition, see below), transported to the laboratory and dissected free from adhering tissue under a microscope. The endothelium was removed from both the cerebral and omental arteries by perfusion for $5 \mathrm{~s}$ with $0.1 \%$ Triton $\mathrm{X}-100$ followed by another $5 \mathrm{~s}$ of perfusion with a physiologic buffer solution (for composition, see below) using a fine needle [19]. The vessels were then cut into cylindrical segments ( $1 \mathrm{~mm}$ long), and were immediately used in the experiments. Each cylindrical segment was mounted on two L-shaped metal prongs, one of which was connected to a force displacement transducer (FT03C) for continuous recording of the isometric tension, and the other to a displacement device [20]. The position of the holder could be changed by means of a movable unit allowing fine adjustments of the vascular resting tension by varying the distance between the metal prongs. The mounted artery segments were immersed in temperature controlled $\left(37^{\circ} \mathrm{C}\right)$ tissue baths containing bicarbonate based buffer solution of the following composition (mmol/L): $\mathrm{NaCl}$ 119, $\mathrm{NaHCO}_{3} 15, \mathrm{KCl} 4.6, \mathrm{MgCl}_{2}$ 1.2, $\mathrm{NaH}_{2} \mathrm{PO}_{4}$ 1.2, $\mathrm{CaCl}_{2} 1.5$ and glucose 5.5 . The solution was continuously gassed with $5 \% \mathrm{CO}_{2}$ in $\mathrm{O}_{2}$ resulting in a $\mathrm{pH}$ of 7.4. Twelve ring segments were studied at the same time in separate tissue baths. The segments were allowed to stabilise at a resting tension of $4 \mathrm{mN}$ (omental arteries) and $2 \mathrm{mN}$ (cerebral arteries) for $1 \mathrm{~h}$ before the experiments were started. The contractile capacity of each vessel segment was examined by exposure to a potassium-rich $(60 \mathrm{mmol} / \mathrm{L})$ buffer solution in which $\mathrm{NaCl}$ was exchanged for an equimolar concentration of $\mathrm{KCl}$ (for composition, see above). When two reproducible contractions had been achieved the vessels were used for further studies.

\section{Vasomotor responses}

Endothelium removal was checked by monitoring responses to acetylcholine at the end of the experiment, in arteries preconstricted by $1 \mathrm{mM}$ UTP. Abolished dilatation indicated a properly removed endothelium [19]. The range of acetylcholine-dilatation that can be observed when the endothelium is intact amounts to $30-70 \%$, for both the human cerebral and omental arteries, depending on the quality of the endothelium after surgery (not published data). Unaffected $\mathrm{K}^{+}$induced contractions indicated intact smooth muscle cell function. As the P2X receptors were quickly desensitised, each artery segment from both the cerebral and omental arteries was exposed to a single concentration of $\alpha \beta$-MeATP and the resultant responses of several segments exposed to different concentrations were added up. In this way, each artery segment was exposed to $\alpha \beta$-MeATP only once and the problem of tachyphylaxia was avoided. These experi- ments are referred to as 'single-concentration'. To study the $\mathrm{P} 2 \mathrm{Y}$ receptor stimulated contractions without interference of simultaneous activation of $\mathrm{P} 2 \mathrm{X}$ receptors, uridine diphosphate UDP, UDP $\beta$, UTP, UTP $\gamma$ S, ADP, ADP $\beta$, ATP and ATP $\gamma S$ were added after P2X receptor desensitisation with $10 \mu \mathrm{mol} / \mathrm{L} \alpha \beta$-MeATP, $8 \mathrm{~min}$ prior to each experiment. As the $\mathrm{P} 2 \mathrm{Y}$ receptors are only very slowly desensitised, these agonists could be added cumulatively to determine concentration-response relationships.

\section{The experimental protocol}

First $60 \mathrm{mM} \mathrm{K}^{+}$was added twice to each vessel segment. Washout was performed for one hour both in between the $\mathrm{K}^{+}$induced responses and before the experiments were started. Thereafter, one concentration of $\alpha \beta$-MeATP was added to each vessel segment. When the effect of this had been monitored for $3 \mathrm{~min}, 10 \mu \mathrm{mol} / \mathrm{L}$ of $\alpha \beta$-MeATP was added to all vessel segments. This was left in the tissue bath for $8 \mathrm{~min}$ before a P2Y receptor agonist was added in increasing concentrations. Only one P2Y receptor agonist was tested per arterial segment. Washout was performed for one hour. Thereafter, $1 \mathrm{mM}$ UTP was used to preconstrict the vessel before acetylcholine was added to examine endothelium function.

\section{RT-PCR}

\section{RNA extraction}

The arteries were carefully dissected and the endothelium was removed (see above). The arteries were snap-frozen in liquid nitrogen immediately after acquisition and total cellular RNA was extracted using TRIzol reagent (Gibco BRL) following the supplier's instructions. The resulting RNA pellet was finally washed with $70 \%$ ice-cold ethanol, air-dried and redissolved in $10 \mu \mathrm{l}$ diethyl-pyrocarbonate (DEPC) treated water. The RNA concentration was determined spectrophotometrically considering a ratio of $\mathrm{OD}_{260: 280} \geq 1.6$ as pure.

\section{$R T-P C R$}

RT-PCR was carried out using the GeneAmp RNA PCR kit (Perkin-Elmer, Foster City, CA, USA) on a GeneAmp PCR system 2400 (Perkin-Elmer). Specific primers for the human $\mathrm{P} 2 \mathrm{X}_{1}, \mathrm{P} 2 \mathrm{Y}_{1}, \mathrm{P} 2 \mathrm{Y}_{2}, \mathrm{P}_{2} \mathrm{Y}_{4}$ and $\mathrm{P} 2 \mathrm{Y}_{6}$ receptors were constructed based on published nucleotide sequences [2125] (see Table 2).

First-strand cDNA synthesis carried out with the Amplitaq RNA-PCR kit (Perkin Elmer) in a $20 \mu$ l volume using random hexamers. Amplification was performed using a modified profile $\left(2 \mathrm{~min}\right.$ at $95^{\circ} \mathrm{C}$ followed by 30 cycles of $1 \min 95^{\circ} \mathrm{C}, 1 \min 55-58^{\circ} \mathrm{C}, 30 \mathrm{sec} .72^{\circ} \mathrm{C}$ and a final extension step of $7 \mathrm{~min}$ at $72^{\circ} \mathrm{C}$ ). The products were separated on a $2 \%$ agarose gel containing $1.0 \mu \mathrm{g} / \mathrm{mL}$ ethidiumbromide and photographed. The DNA Ladder $100 \mathrm{bp}$ (Promega Co.) was used as molecular weight marker. As 
these P2 receptors are intronless within their coding regions, PCR without the RT-step was always used to exclude genomic DNA contamination.

\section{Ethics}

The project was approved by the Ethics Committee of Lund University in Sweden.

\section{Drugs}

Vasomotor studies

Acetylcholine, ADP $\beta$, ATP, ATP $\gamma$, UDP, UTP and $\alpha \beta$ MeATP were purchased from Sigma Co. (USA). UDP $\beta S$ and UTP $\gamma \mathrm{S}$ were kind gifts from Inspire Pharmaceuticals, Inc. All drugs were dissolved in $0.9 \%$ saline.

\section{$R T-P C R$}

Oligonucleotides were obtained from Gibco, BRL. If not stated otherwise, all reagents for the RT-PCR assay were purchased from Sigma Co. (USA).

\section{Calculations and statistics}

The negative logarithm of the drug concentration that elicited $50 \%$ contraction $\left(\mathrm{pEC}_{50}\right)$ was determined by linear regression analysis using the values immediately above and below half-maximum response. $\mathrm{E}_{\max }$ refers to maximum contraction calculated as percent of the contractile capacity of $60 \mathrm{mmol} / \mathrm{L} \mathrm{K}^{+}$. The experiments were performed on arteries from six patients and statistical significance was accepted when $\mathrm{P}<0.05$, using Student's $t$-test. All differences referred to in the text have been statistically verified. Values are presented as means \pm S.E.M. RT-PCR experiments were performed on three patients.

\section{Authors' contributions}

Malin Malmsjö: Designed the study and performed the pharmacological experiments and wrote the manuscript.

\section{Mingyan Hou: Performed the RT-PCR experiments.}

William Pendergast: Supplied the stable pyrimidines and proof-read the manuscript.

David Erlinge: Conceived the study and participated in writing the manuscript.

Lars Edvinsson: Guided throughout the study and participated in writing the manuscript.

\section{Acknowledgements}

This study has been supported by the Swedish Hypertension Society, the Royal Physiographic Society (Lund), The Swedish Migraine Society, the Heart and Lung Foundation, the Swedish Medical Association and The Swedish Medical Research Council Grant X0667 and 5958. The authors wish to thank Inspire Pharmaceuticals Inc. for supplying us with UDP $\beta$ S and UTP $\gamma$ S.

\section{References}

I. Burnstock G Purinergic signaling and vascular cell proliferation and death Arterioscler Thromb Vasc Biol 2002, 22:364-73

2. Burnstock $G$ Release of vasoactive substances from endothelial cells by shear stress and purinergic mechanosensory transduction J Anat 1999, 194:335-42

3. Ralevic $V$ and Burnstock $G$ Receptors for purines and pyrimidines Pharmacol Rev 1998, 50:413-92

4. Shirasawa $Y$, White RP and Robertson JT Mechanisms of the contractile effect induced by uridine 5-triphosphate in canine cerebral arteries Stroke 1983, 14:347-55

5. Keppler D, Rudigier J and Decker K Enzymic determination of uracil nucleotides in tissues Anal Biochem 1970, 38:105-14

6. Urquilla PR Prolonged contraction of isolated human and canine cerebral arteries induced by uridine 5 '-triphosphate Stroke 1978, 9:133-6

7. Miyagi $Y$, Kobayashi S, Nishimura J, Fukui $M$ and Kanaide $H$ Dual regulation of cerebrovascular tone by UTP: P2U receptor-mediated contraction and endothelium-dependent relaxation BrJ Pharmacol 1996, I I 8:847-56

8. Evans RJ, Surprenant A and North RA P2X receptors In: The P2 nucleotide receptors (Edited by: Turner JT, Weisman GA, Fedan JS) Totowa, NJ: Human Press Inc 1998, I09-134

9. Harden TK, Nicholas RA, Schlater JB, Lazarowski ER and Boyer JL Pharmacological selectivities of molecularly defined subtypes of $\mathbf{P} 2 \mathbf{Y}$ receptors In: The P2 nucleotide receptors (Edited by: Turner JT, Weisman GA, Fedan JS) Totowa, NJ: Human Press Inc 1998, $109-134$

10. Hansen MA, Dutton JL, Balcar VJ, Barden JA and Bennett MR P2X (purinergic) receptor distributions in rat blood vessels J Auton Nerv Syst 1999, 75:147-55

II. Lewis CJ and Evans RJ Comparison of $\mathbf{P 2 X}$ receptors in rat mesenteric, basilar and septal (coronary) arteries J Auton Nerv Syst 2000, $81: 69-74$

12. Valera S, Hussy N, Evans RJ, Adami N, North RA, Surprenant A and Buell $G$ A new class of ligand-gated ion channel defined by $P 2 x$ receptor for extracellular ATP Nature 1994, 37 I:516-9

13. Léon C, Hechler B, Vial C, Leray C, Cazenave JP and Gachet C The P2YI receptor is an ADP receptor antagonized by ATP and expressed in platelets and megakaryoblastic cells FEBS Lett 1997, 403:26-30

14. Palmer RK, Boyer JL, Schachter JB, Nicholas RA and Harden TK Agonist action of adenosine triphosphates at the human P2YI receptor Mol Pharmacol 1998, 54: I I I 8-23

15. Nicholas RA, Watt WC, Lazarowski ER, Li Q and Harden K Uridine nucleotide selectivity of three phospholipase C-activating P2 receptors: identification of a UDP-selective, a UTP-selective, and an ATP- and UTP-specific receptor Mol Pharmacol 1996, 50:224-9

16. Gordon JL Extracellular ATP: effects, sources and fate Biochem J 1986, 233:309-19

17. Hou M, Harden TK, Kuhn CM, Baldetorp B, Lazarowski E, Pendergast W, Moller S, Edvinsson L and Erlinge D UDP acts as a growth factor for vascular smooth muscle cells by activation of P2Y(6) receptors Am J Physiol Heart Circ Physiol 2002, 282:H784-92

18. Lazarowski ER, Watt WC, Stutts MJ, Brown HA, Boucher RC and Harden TK Enzymatic synthesis of UTP gamma $S$, a potent hydrolysis resistant agonist of P2U-purinoceptors $\mathrm{Br} J$ Pharmacol 1996, I I 7:203-9

19. Hamel E, Assumel-Lurdin C, Edvinsson L, Fage D and MacKenzie ET Neuronal versus endothelial origin of vasoactive acetylcholine in pial vessels Brain Res 1987, 420:391-6

20. Högestatt ED, Andersson KE and Edvinsson L Mechanical properties of rat cerebral arteries as studied by a sensitive device for recording of mechanical activity in isolated small blood vessels Acta Physiol Scand 1983, I I 7:49-6I

21. Communi D, Pirotton S, Parmentier M and Boeynaems JM Cloning and functional expression of a human uridine nucleotide receptor J Biol Chem 1995, 270:30849-52

22. Communi D, Parmentier M and Boeynaems JM Cloning, functional expression and tissue distribution of the human P2Y6 receptor Biochem Biophys Res Commun 1996, 222:303-8

23. Parr CE, Sullivan DM, Paradiso AM, Lazarowski ER, Burch LH, Olsen JC, Erb L, Weisman GA, Boucher RC and Turner JT Cloning and expression of a human P2U nucleotide receptor, a target for 
cystic fibrosis pharmacotherapy Proc Natl Acad Sci U S A 1994 , 9I:3275-9

24. Valera S, Talabot F, Evans RJ, Gos A, Antonarakis SE, Morris MA and Buell GN Characterization and chromosomal localization of a human P2X receptor from the urinary bladder Receptors Channels 1995, 3:283-9

25. Léon C, Vial C, Cazenave JP and Gachet C Cloning and sequencing of a human CDNA encoding endothelial P2YI purinoceptor Gene 1996, 171:295-7

26. Malmsjö M, Hou M, Harden TK, Pendergast W, Pantev E, Edvinsson $L$ and Erlinge $D$ Characterization of contractile $P 2$ receptors in human coronary arteries by use of the stable pyrimidines uridine 5'-O-thiodiphosphate and uridine 5'-0-3-thiotriphosphate J Pharmacol Exp Ther 2000, 293:755-60

27. Malmsjö M, Adner M, Harden TK, Pendergast W, Edvinsson L and Erlinge $D$ The stable pyrimidines UDPbetaS and UTPgammaS discriminate between the $\mathbf{P 2}$ receptors that mediate vascular contraction and relaxation of the rat mesenteric artery $\mathrm{Br}$ J Pharmacol 2000, 13 1:51-6

28. Shirahase $H$, Usui $H$, Manabe $K$, Kurahashi $K$ and Fujiwara M Endothelium-dependent contraction and -independent relaxation induced by adenine nucleotides and nucleoside in the canine basilar artery J Pharmacol Exp Ther 1988, 247: I 152-7

29. Sima B, Macdonald L, Marton LS, Weir B and Zhang J Effect of P2purinoceptor antagonists on hemolysate-induced and ade-

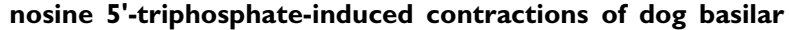
artery in vitro Neurosurgery 1996, 39:815-21

30. Sima B, Weir BK, Macdonald RL and Zhang H Extracellular nucleotide-induced $[\mathrm{Ca2}+]$ i elevation in rat basilar smooth muscle cells Stroke 1997, 28:2053-8

31. Toda N, Okunishi H, Taniyama K and Miyazaki M Responses to adenine nucleotides and related compounds of isolated dog cerebral, coronary and mesenteric arteries Blood Vessels 1982, 19:226-36

32. Lewis CJ, Ennion SJ and Evans RJ P2 purinoceptor-mediated control of rat cerebral (pial) microvasculature; contribution of P2X and P2Y receptors J Physiol 2000, 527(Pt 2):315-24

33. Bo X, Karoon P, Nori SL, Bardini M and Burnstock G P2X purinoceptors in postmortem human cerebral arteries J Cardiovasc Pharmacol 1998, 31:794-9

34. Wihlborg A-K, Malmsjö M, Eyjolfsson A, Gustafsson R, Jacobson K and Erlinge $D$ Extracellular nucleotides induce vasodilatation in human arteries via prostaglandin, nitric oxide and endothelium-dependent hyperpolarizing factor $\mathrm{Br} J$ Pharmacol

35. Hardebo JE, Kahrstrom J, Owman C and Salford LG Endotheliumdependent relaxation by uridine tri- and diphosphate in isolated human pial vessels Blood Vessels 1987, 24:150-5

36. Lazarowski ER, Homolya L, Boucher RC and Harden TK Identification of an ecto-nucleoside diphosphokinase and its contribution to interconversion of $\mathbf{P 2}$ receptor agonists J Biol Chem 1997, 272:20402-7

Publish with Bio Med Central and every scientist can read your work free of charge

"BioMed Central will be the most significant development for disseminating the results of biomedical research in our lifetime. "

Sir Paul Nurse, Cancer Research UK

Your research papers will be:

- available free of charge to the entire biomedical community

- peer reviewed and published immediately upon acceptance

- cited in PubMed and archived on PubMed Central

- yours - you keep the copyright

Submit your manuscript here:

http://www.biomedcentral.com/info/publishing_adv.asp
BioMedcentral 